\title{
The Role of Women in Village Development in Percut Village District Percutsei Tuan, Deli Serdang Regency
}

\author{
Beby Masitho Batubara*, Riri Rezeky Hariani \\ Lecturer at Faculty of Politics and Social Science, University of Medan Area, Indonesia
}

*Corresponding Author: Beby Masitho Batubara, Lecturer at Faculty of Politics and Social Science,

University of Medan Area, Indonesia

\begin{abstract}
The purpose of this study was to determine the role of women in village development in Percut Village, PercutSei Tuan Sub district and the factors affecting the role of women in village development in Percut Village. This type of research is a qualitative descriptive study. Type of qualitative research with descriptive research type, namely a study that aims to provide a factual picture with the right argument. Primary data collection techniques using interviews and observations, while secondary data collection techniques, namely Library Research (Library Research). The results of this study indicate that the role of women in village development precisely in the village of Percut, can still be said to be not going well, where the weak role of community organizations in the supervision and dissemination of law and not yet realized, gender equality and justice, this is exacerbated by the still limited women's involvement in the process of making public policy decisions and the exclusion of women in the implementation of the Musrenbang. Factors that influence the role of women in rural development are internal factors and external factors. Where internal factors come from within, namely the lack of facilities and infrastructure in terms of community empowerment and the lack of knowledge of the village government and the community related to uptudate information related to the Village Fund. Meanwhile, external factors are: the lack of budgetary resources in the implementation of women's empowerment and the apathy of women's attitudes in decision making and participation in Musrenbang activities.
\end{abstract}

Keywords: Peranan, Perempuandan Pembangunan

\section{INTRODUCTION}

In its existence in the midst of society, women cannot escape from the various perspectives that accompany it. It may be that people articulate women from the standpoint of their characteristics, their role in society, family, education and others. As for women from a historical point of view plays many roles. Women as mothers, wives, farmers, company managers, voluntary workers, village heads and others. More than that the role of women in Indonesia in general, has been very instrumental in the political fields of government such as the President of the Republic of Indonesia, the Governor, the Minister, the District Head and so forth. This further confirms that women in their lives not only play multiple roles but are multi-role in society.

The state of the role and status of women today is more influenced by the past, culture, ideology, and daily life practices. This is the key why women's participation in community and state life experiences weakness. The low quantitative representation of women in activities in the village such as: Musrembang and other social activities, it is this formal which then encourages and motivates the birth of various kinds of demands so that women are given more space to participate. The role played by women in their participation in the development sector is an act in the context of lifting the dignity and quality of women themselves.

The involvement of women is an absolute requirement in an effort to realize equitable development. The state cannot be prosperous if the women are left behind. Excluded and oppressed. As stated by Vivekananda that a State and Nation that does not respect its women will never be great, both now and in the future. One fundamental reason for causing your nation to fall drastically is because you have no respect for the lives of women described as wives. So that the complete and comprehensive development of a country requires the full role of women in all fields of life. That women, both as citizens and as sources of development, have the same rights, obligations and opportunities as men in 
all development activities in all areas of life. The role of women has also been accommodated by all National development regulations, such as Law No. 6 of 2014 on Villages, which present the involvement of women which is indispensable for the success of village development.

In Percut Village itself, the role of women in all aspects of development is very weak, ranging from exclusion from village facilitation development, maintaining village security, Musrembang and so forth. It's just that the problem in the village is related to this role, in fact there is very little role of women in the leadership of Percut Village such as the lack of women in occupying positions in the Village, less in positions in the Village apparatus. This is interesting to study because changes in society have pushed aside the role of these women, so it is necessary to look for the root of the problem.

Role is a dynamic aspect of the position (status). This means that someone has exercised their rights and obligations in accordance with their position, then that person has carried out a role. The two cannot be separated because each other is interdependent, meaning there is no role without status and no status without role. As is the position, then every person can have a variety of roles that originate from the pattern of social interaction. It also means that the role determines what he does for the community and what opportunities the community gives him. The role is very important because it can regulate a person's behavior, in addition to that the role causes a person to predict the actions of others at certain limits, so that someone can adjust his own behavior to the behavior of the people of his group.

According to VeithzalRivai, said role is a person's behavior that is expected to make a change and hope that leads to progress, although not always in accordance with what is expected and as a benchmark for someone as a leader whether that person can improve performance in carrying out the tasks given to him so that will make the person can maximize performance in carrying out their duties. Roles are defined from each expert including the role can be interpreted as behavior that is regulated and expected from someone in a certain position. The leader in an organization has a role, every job brings hope how the guarantor's role behaves. The fact that the organization identifies the work that must be and the desired role behavior that goes along with the work also implies that expectations regarding the meaning of the important role in regulating the behavior of subordinates[1].

Role is a dynamic aspect of the status (status) if a person carries out his rights and obligations then he carries out a role. The concept of role is as follows:

- Part of the main task that must be carried out by management

- The pattern of behavior that is expected to accompany a status

- A part of a person's function in a group or target

- The function that is expected of someone or is characteristic of him

- The function of each variable in a causal relationship

The role is a set of expectations imposed on individuals or groups to carry out the rights and obligations that must be carried out by the stakeholders in accordance with what is expected by the community. Every person has a variety of roles that come from the patterns of social interaction. This also means that the role determines what is done for the community and what opportunities are given by the community to him [2].

The village as the lowest government organization is the foundation of all government and development affairs, with various potential resources they have. The existence and life of the village, as a community unit where a number of residents reside who are entitled to manage their own households is a community organization that has long predated the formation of the State of Indonesia.

Furthermore according to Dwipayana village "an area occupied by a number of residents as a legal community unit that has the lowest government organization directly under the camat" becomes a formula that reads "village as a legal community unit that has the authority to regulate and manage the interests of the local community based on the origin of the village "So that this formula can be interpreted simply as the power of villages to create and develop village policies that are tailored to the customs, needs and aspirations of their citizens[3]. 
Law of the Republic of Indonesia Number 23 of 2014 concerning Regional Government, concerning village government, namely the village or referred to by other names, hereinafter referred to as village, is a legal community unit that has jurisdictional boundaries, has the authority to regulate and manage the interests of the local community based on the origins and local customs which are recognized and or established in the 1945 Constitution of the Republic of Indonesia. Government Regulation of the Republic of Indonesia Number 72 of 2005 concerning villages, namely villages, is a legal community unit that has territorial boundaries that are authorized to regulate and administer the interests of the local community, based on local origins and customs that are recognized and respected in the Government of the Unitary State of the Republic of Indonesia. [4]

In Indonesia the discussion and resolution of women or women is as important as the discussion and resolution in all fields. Women are only considered as subjects whose job is a commitment to spend salary or income earned by their husband. Such an opinion cannot be justified, because it is realized that women are also capable of earning a living or salary to get alternative income and achievement. Based on the description above, the understanding of the dual role of women in development is the activities, tasks or participation of women which includes the present sector of the cosmetics and public sector which is known as the period of development [5].

Women as holders of important and even important roles in politics are not new things in the history of the life of this nation. As is well known that women have become important actors in the struggle of nationalists in the public sphere that marked the entry of this nation into the era of modernity. It can be said that pre-modernity is always accompanied by a development process. Understanding the development process is a change in social culture that will include changes in values. Aside from being a wife, women are expected to be active in the organization where the husband works, because the wife's status as a husband's assistant and according to information also determines the husband's condition. To be able to participate properly in society, education is an absolute requirement [6]. Shifts and roles (division of labor) between men and women in the family and household, occur when a mother has a very important role in society and the country. Where the role of women is not only to be led but also to lead. It must get positive and certain recognition.

The division of private and public roles is not relevant if applied in public society. This is especially true in the PercutSei Tuan community, where women take care of the household. The pattern of private and public division has actually been broken by the ideology of production which adheres to structural functionalism. This understanding says that the private-public division is contrary to the ideology of production. According to the ideology of production, women also produce. Dlam Sociological Theory or in the elaboration of sociological theory, Parsons said that although the measurements used to assess the status of women and men are different, but the status of women is the same as the status of men. The pattern of marriage according to Parsons, is a relationship between two people who are equal [7]. In the sense that the status of a woman is obtained on the basis of the status of husband and wife, and can also be obtained on the basis of her workposition.

Basically the role of women is very necessary to preserve a culture that is very useful for the next generation. Not only do women need to be improved in their knowledge, abilities and skills, but women must have greatness of soul and nobility. For the success of development, the participation of women is needed, therefore encouragement, moral assistance and understanding from the men of the husband in particular are needed.

\section{MATERials \&MethodS}

\subsection{Research Design}

The type of research used is qualitative research with descriptive research type, namely a study that aims to provide a factual picture with the right arguments. Therefore, this study aims to understand the role of women in village development in the village of PercutSei Tuan. Qualitative research methods are research methods used to examine natural object conditions, (as opposed to experiments) where the researcher is a key instrument, data collection techniques are performed triangulated (combined), data analysis is inductive, and qualitative research results emphasize more meaning rather than generalization.[8]

\subsection{Research Informant}

Research Informants are people who provide the information needed during the research process. The 
informants of this research include key informants and additional informants. Key informants are those who know and have a variety of basic information needed in research or informants who know deeply the problem under study. The Key Informants in this study are: Secretary of the Lurah, and the village community of Percut Village. Additional informants are those who provide information even though they are not involved in the social interactions under study. The additional informant in this study was the Chairperson of TP-PKK in PercutVillage.

\subsection{Data Collecting Technique}

Primary data collection techniques using interviews, namely data collection techniques by asking questions directly to the parties related to the research conducted and subsequently will be referred to as informants. Furthermore, making observations, namely activities directly observing the object of research by recording symptoms found in the field and encompassing inaccessible data. Secondary data collection techniques using library research (Library Research), namely by collecting data and information through literature that is relevant to research titles such as books, papers and magazines that have relevance to the problem under study, then Documentary Studies (i.e. Documentary) by using the legal documents in the records of the research location and other sources relevant to the object of research. [9]

\subsection{Data Analyze Tehnique}

Analysis of the data used in this research is qualitative analysis. Where according to Miles, qualitative data analysis is about using words that are always arranged in a text that is extended or described. Qualitative data analysis is based on facts or information in the field then selected and developed into meaningful questions. Whereas for data analysis it is very necessary, as stated data analysis as a process that seeks formal efforts to find themes and formulate ideas as suggested by the data and as an effort to provide assistance and themes to the idea. Analysis data in qualitative methods are carried out simultaneously through the process of collecting data [10]. Data analysis includes the collection of research data to record all data objectively and as is in accordance with the results of observations and interviews in the field, data reduction is to choose the main things in accordance with the focus of the study. Reduction is a form of data analysis that classifies, directs, discards unnecessary and organizes data that has been reduced, provides a sharper picture of the observations and makes it easier for researchers to find it if at any time is needed and the presentation of data. [11]

\section{RESULTS \& DISCUSSION}

\subsection{Results}

\subsubsection{General Overview of PercutSei Tuan District}

PercutSei Tuan sub-district office is located on JalanBesarTembung Number 22, which is on the Medan-Batang Quiz line. With this office position, it is very strategic to be driven by vehicles from various directions, so that people who deal with PercutSei Tuan sub-district office can easily reach it both by public vehicles and by personal vehicles of motorbikes and cars. As a government service center in the sub-district area, the PercutSei Tuan sub-district office is classified as one of the oldest sub-district offices in Deli Serdang Regency. Along with the proclamation of the independence of the Republic of Indonesia in 1945, the PercutSei Tuan Subdistrict Office was established even though it was in the preparation stage.

Thus, the existence of the PercutSei Tuan Sub-District Office since the beginning of independence with different names such as Assistant Wedana to the Camat, then government services, development and community services have been carried out. PercutSei Tuan Subdistrict Office is classified as type "A", the standard status of type "A" is seen from the number of population, area, dynamics of administrative services, the composition of village and village government under his supervision. In 2009 PercutSei Tuan sub-district consisted of 2 villages and 18 villages.

\subsubsection{General Overview of Percut Village, Sei Tuan District}

Percut Village is at an altitude of $2 \mathrm{~m}$ above sea level and is a low-lying area. Meanwhile, rainfall reaches $0-278 \mathrm{~mm} /$ year with temperatures around $23^{\circ} \mathrm{C}-30^{\circ} \mathrm{C}$. There are two seasons known as the rainy season and the dry season. The dry season usually lasts three months, which is June to August, while the rainy season lasts nine months, which is between September to May. 
For more details, Percut Village has the following boundaries:

- North side is bordered by Malacca Strait

- The south is bordered by DesaCinta Rakyat

- West side is bordered by TanjungRejo Village

- East side is bordered by CintaDamai Village and PematangLalang Village

The area of Percut Village is 1063 ha, where it is estimated that around 740 ha is land that can be used as for rice fields and cultivation, while the rest is around 323 ha intended for settlements around 102 ha, roads, ponds, burial around 15 ha, offices and others -other. And 180 ha of land is used for green belt. Land designated as a green belt covering an area of 180 ha is a coastal area overgrown with mangrove plants. This green belt is intended to avoid abrasion from the sea into the plains and as a place for several well-developed marine habitats. However, according to observations, the green line has partially converted (converted) into settlements and aquaculture.

\subsubsection{Situation of Percut Villagers}

Percut Village consists of 18 neighborhoods / hamlets, each led by the Head of the Environment, in 1980 in Percut Village PercutSei Tuan District was inhabited by approximately 15,812 people. The population has changed from year to year, this is due to the birth rate and the immigrant population coming to this area. The population in this village consists of various ethnic groups, but the majority of the population are Malay, as an indigenous tribe inhabiting this area. In addition there are also residents of the Toba Batak tribe, Mandailing, Javanese, Karo, Simalungun and some other non-native residents. Following is an explanation of the population in Percut Village, PercutSei TuanDistrict:

Table1: DesaPercut Population Amount

\begin{tabular}{|l|l|l|}
\hline No. & \multicolumn{1}{|c|}{ Amount } \\
\hline 1. & Male & 7.756 \\
\hline 2. & Female & 8.056 \\
\hline & Total & $\mathbf{1 5 . 8 1 2}$ \\
\hline
\end{tabular}

(Source: DesaPercutTahun 2019)

\subsubsection{Overview of the Role of Women in Percut Village, PercutSei Tuan District}

Based on observations made, the authors see that the role of women in Percut Village, has not run optimally and can still be said to be weak. This is proven by the absence of women's participation in many activities, such as Musrenbang activities, seminars, recitation, posyandu and so on. Though all forms of women's activities have been formed in the PKK Village Percut. But the PKK could not be felt and carried out by all the women in Percut Village.

\subsection{Discussion}

\subsubsection{The Role of Women in Village Development Women}

This is important in line with the implementation of the Village Law and the disbursement of the Village Fund so that more people are aware of village authority based on the origin and authority of the village on a local scale. The embodiment of these two powers could encourage the Village movement towards a prosperous Village. The role of women in village development will increase the opportunities for women themselves to overcome their problems through the village development process. The ongoing village development process must accommodate the aspirations and needs of women. In another part, women also need to involve themselves in the political process and development in their villages. This is important so that women are not just being the target of discussion and the object of development alone.

In some villages, village development is still in the usual gender and less attention to important aspects needed by women to live healthy, prosperous and open their active roles. So women need to fight for themselves so that the role in the village development process can be achieved and implemented properly. In the Village Law it is stated that the Village Authority covers the authority in the field of administering the Village Government, the implementation of the Village Development, the fostering of the Village community, and the empowerment of the Village community based on 
community initiatives, rights of origin, and village customs. The village has dozens of authorities both based on origin and local village scale authority. Plus the authority of the village assigned by the Government, Provincial Government, or Regency / City Government; and other authorities assigned by the Government, Provincial Government, or Regency / City Government in accordance with statutory provisions.

There are many roles that can be taken and played by village women in the context of implementing village development. Seen from the authority of the village that has been regulated in Permendesa No. 1 of 2015 there is regulated what authority the village has as the basis and power to carry out development and improve the welfare of the villagers. Women can take on many development roles there, further and deeper than PKK, dasawisma, posyandu, PAUD Desa, Musrenbang and raskin. Village authorities almost all open opportunities for women to play it. There is no requirement that village authority must be held and exercised by men. That there are many obstacles and challenges to get there, that is what needs to be answered by the village women themselves and the village government. The level of women's involvement in village development from year to year needs to be monitored and encouraged to increase.

The implementation of the village government as one of the local scale village authorities actually opens the role of women either as individuals or institutions that facilitate women. Among those authorities are Making Regulations in the Village; Plan, implement, monitor and control village development; Managing Village Finances; Doing Village Charges; Managing Village Assets; Administrative Administration and Village Archives. In addition, women can also involve themselves in conducting inter-village cooperation; Cooperating with third parties; Setting village boundaries and poverty alleviation.

In Percut Village, development is not only physical, but also non-physical. For example in the form of empowerment from PKK, Perempaun Group, Posyandu and so on. These elements of women have a role in providing input and proposals to the Percut Village Head in deciding on the village development planning process. So the proposals for each hamlet include proposals from the female element, then taken to the village to choose which is prioritized. In the Village Development Planning Consultation (MUSRENBANG Desa) in Percut Village, there were no women who brought the proposal. However, the development process in Percut Village has always intensified community participation. Because in principle, all village development processes themselves are carried out for the benefit of the people of Percut Village. The priority scale of the Musrenbang in Percut Village itself prioritizes development in Percut Village, because what the community itself needs is the construction of roads, the management of certificates, and assistance to rehabilitate residents' homes. And the results of the Percut Village Musrenbang are then brought down to the District level. The Village Representative of Percut when submitting the proposal to the Sub-district itself was the VillageHead.

Even though there are many influences from the activities carried out by the PKK because these activities carry out training and counseling for women citizens so that the residents of Percut Village have some expertise such as sewing, embroidering, making stalk flowers and making traditional snacks. This certainly provides provisions for women citizens in carrying out economic activities, for example there are women citizens by making businesses making peyek, chips, flowers. The PKK team also often held competitions during the celebration. Indonesian Independence Day every August 17. However, this cannot be done by women in Percut Village, women's participation and participation in Percut Village is still quite weak.

Based on observations made by researchers, the low level of education in the village of Percut is also a major problem that must be resolved immediately by the local government. Development of educational facilities has become an urgent need for community members. It is hoped that with the availability of educational facilities, more residents will be able to send their children to higher levels of education. With a higher level of education, it is expected that the community can occupy better job positions so as to improve the family's standard of living.

In this case, women can also develop knowledge and have income so that they can share their domestic roles with men. Of course needed support from the government, especially the Village apparatus in the form of effective and maximum actions for example in the management of the 
Village Fund and the use of Perhutani land. Thus it is hoped that Percut Village can achieve progress and be able to stand on its own feet. Women can also have the sovereignty to choose a job that suits their abilities.

Therefore, a village will be considered noble if it is considered successful in managing women's potential. Moreover, the female population in Percut Village is more dominant than the number of men. Therefore, the potential of women must be managed well by empowering women in all fields of development. So it is hoped that women in Percut Village need to be prepared to prepare themselves to fill the portion in exercising village authority based on original rights. For example, by becoming a village official, being involved in a customary community organization system, engaging in community institutional development or participating in fostering traditional institutions andlaws.

Rural development in the context of community empowerment to build independence and community welfare needs to be done in order to form and create a civil society. In the process, it must focus on the participation and involvement of all elements of the community who are in the Village as a driving factor. The key to implementing development so that it can run optimally is to utilize all local resources in the village, human resources must also be utilized properly, by not looking at gender as a divider between men and women.

The element of empowerment must actually provide a gap for women to be able to work and be creative. Women today cannot be seen as women in ancient times because in their development, it turns out that women can also contribute in the form of ideas, energy, and time in creating an innovation that can be applied in villages for rural development. We can see in big cities, once empowered women in the field of industry and offices they are productive women workers. Things like that actually prove that today women can no longer be seen as marginalized people. To create maximum collaboration in building a better village, collaboration between various elements must be invited to unite one vision and mission without dichotomizing gender as a gap that can separate.

However, in order to encourage women's participation in determining development policies at the Percut Village level, the Percut Village Government continues to make various efforts by forming TPPKK which includes women's groups. TP-PKK conducts various forms of women's training such as: making chips, flower making, social gathering activities and recitals.

This activity is carried out to increase the role of women in various forms of activities. But what happened in Percut Village, the activities that were attended by women were only empowerment activities such as handicraft training and recitation, but in terms of participation in musrenbang activities women entrusted entirely to men. Then it can be said that the role of women has not been maximized in village level forums. Women in Percut Village have not been involved in the decision making process related to development policy. In the future, it is hoped that women's participation will emerge that can influence village governance policies.

\subsubsection{Factors Affecting the Role of Women in Village Development in Percut Village}

In implementing development in the village, of course the village government requires the role of women in village development, especially in the village of Percut. Of course there are many factors that influence the role of women in village development. Based on data from interviews and observations, it can be seen that internal factors which become obstacles in the role of women in village development, namely inadequate facilities and infrastructure, in this case there are still many needs of the female community that have not been met such as special reading rooms, discussion rooms for women and the lack of training on women's empowerment related to village development. The lack of knowledge of the community and the village government of Percut, in this case the level of education has a major influence on the ability of employees, and the community, because some female employees and communities in the village of Percut have education only up to advanced level.

Based on data from interviews and observations, external factors that become obstacles in the role of women in village development in the village of Percut, namely: the lack of budget from the government in empowering women in the village, so that this causes the lack of knowledge and understanding of women towards village development policies. In this case also the community is less aware of the importance of development in a village. The community tends to be apathetic, in this case all women in Percut Village have never attended meetings and musrenbang in the Percut Village. 


\section{CONCLUSION}

The role of women in village development, precisely in Percut village, can still be said to be not going well, where the weak role of community organizations in monitoring and disseminating the law and not yet being realized, gender equality and justice, this is exacerbated by the limited involvement of women in the process of taking public policy decisions and the exclusion of women in the implementation of the Musrenbang. Factors that influence the role of women in rural development are internal factors and external factors. Where internal factors come from within, namely the lack of facilities and infrastructure in terms of community empowerment and the lack of knowledge of the village government and the community related to uptudate information related to the Village Fund. Meanwhile, external factors are: the lack of budget resources in the implementation of women's empowerment and the apathy of women's attitudes in decision making and participation in Musrenbang activities.

\section{REFERENCES}

[1] Adedevi. 2013. Konsep Peran Menurut Beberapa Ahli. http://carapedia.com/ pengertian definisi peran info 2184.html.pdf diakses tanggal 14 November 2013 pukul 17.00WIB

[2] Juraidih, 2011. Peranan Pemerintah Desa Dalam Meningkatkan Partisipasi Masyarakat Terhadap Pembangunan. di Desa Mendik Karya Kecamatan Long Kali Kabupaten Paser Journal Administrasi Negara, journal.an.fisipunmul.ac.id

[3] Beratha, I Nyoman. 1981. Masyarakat Desa dan Pembangunan Desa. Jakarta:Ghalia

[4] Undang-Undang Desa No 6 Tahun 2016 TentangDesa

[5] Juraidih, 2011. Peranan Pemerintah Desa Dalam Meningkatkan Partisipasi Masyarakat Terhadap Pembangunan. di Desa Mendik Karya Kecamatan Long Kali Kabupaten Paser Journal Administrasi Negara, journal.an.fisipunmul.ac.id

[6] Ihromi, T.O. 1995. Kajian Wanita Dalam Pembangunan. Yayasan Obor Indonesia.Jakarta

[7] Lita S. 2014. Peran Perempuan di Sektor Domestik dan Sektor Publik ( Studi Kasus di PT. Perkebunan Nusantara III Medan). Skripsi. Universitas Sumatera Utara.Medan

[8] Burhan, Bungin, (2003), Analisis Data Penelitian Kualitatif, PT. Raja Grafindo Persada,Jakarta.

[9] Moleong, Lexy J. 2013. Metode Penelitian Kualitatif. Edisi Revisi. Bandung : PT. RemajaRosdakarya

[10] Bogdan, Robert dan Taylor,Pengantar Metode Penelitian Kualitatif, Terjemahan oleh Arief Rurchan, (Surabaya : UsahaNasional,

\section{AUTHORS' BIOGRAPHY}

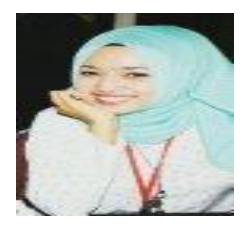

Beby Masitho, M.AP is Lecturer at Faculty of Politics and Social Science, Majority of Public Administration, University of Medan Area, Indonesia.

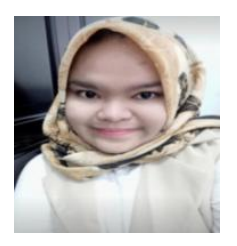

Riri Rezeki Hariani, M.AP is Lecturer at Faculty of Politics and Social Science, Majority of Public Administration, University Of Medan Area, Indonesia.

Citation: Beby Masitho Batubara, Riri Rezeky Hariani. "The Role of Women in Village Development in Percut Village District Percutsei Tuan, Deli Serdang Regency". International Journal of Humanities Social Sciences and Education (IJHSSE), vol. 6, no. 10, 2019, pp. 46-53. doi: http://dx.doi.org/10.20431/2349-0381. 0610005 .

Copyright: (C) 2019 Authors. This is an open-access article distributed under the terms of the Creative Commons Attribution License, which permits unrestricted use, distribution, and reproduction in any medium, provided the original author and source are credited. 